\title{
PENENTUAN RUTE TERPENDEK MENUJU PUSAT PERBELANJAAN DI JAKARTA MENGGUNAKAN ALGORITMA DIJKSTRA
}

\author{
Jodi Setiawan $^{1}$, Rezy S. Prakoso², Kristien Margi Suryaningrum ${ }^{3}$ \\ Mahasiswa Universitas Bunda Mulia ${ }^{1,2}$, Dosen Universitas Bunda Mulia ${ }^{3}$ \\ Jalan Lodan Raya, RT.12/RW.2, Ancol, Kec. Pademangan, Kota Jakarta Utara, \\ Daerah Khusus Ibukota Jakarta \\ Sur-el : jodi.set2106@gmail.com¹, reji0599@gmail.com², kristienmargi@gmail.com³
}

\begin{abstract}
Shopping centers are easy to find in big cities like Jakarta and because there are too many times people are often confused which one to go to, not to mention if people from outside Jakarta come and want to visit a shopping center. The problem to choose a shopping center that encourages researchers to conduct a study to develop applications to find the nearest shopping center using the Dijkstra algorithm that can be used on smartphones in order to make it easier to find and find shopping centers around users. The application was designed using flowchart and UML and was made using Android Studio with the help of the Google Maps API to display maps, display pins, find and display the nearest route using latitude and longitude from Google Maps. Algorithm to calculate and determine the route that must be traversed using the Dijkstra algorithm. The accuracy of the calculation results using the Dijkstra algorithm reaches $93 \%$.
\end{abstract}

Keywords: Dijkstra, Google Maps API, Android Studio, Graph

\begin{abstract}
Abstrak : Pusat perbelanjaan mudah ditemui di kota-kota besar seperti di Jakarta dan karena jumlahnya yang terlalu banyak sering kali orang-orang bingung untuk pergi ke pusat perbelanjaan yang mana, belum lagi jika orang-orang dari luar Jakarta datang dan ingin mengunjungi suatu pusat perbelanjaan. Permasalahan untuk memilih pusat perbelanjaan itu yang mendorong peneliti melakukan sebuah penelitian untuk mengembangkan aplikasi untuk mencari pusat perbelanjaan terdekat dengan menggunakan algoritma Dijkstra yang dapat digunakan pada smartphone agar memudahkan untuk mengetahui dan menemukan pusat perbelanjaan yang ada di sekitar pengguna. Aplikasi dirancang menggunakan flowchart dan UML dan dibuat dengan menggunakan Android Studio dengan bantuan Google Maps API untuk menampilkan peta, menampilkan pin, mencari dan menampilkan rute terdekatnya menggunakan latitude dan longitude dari Google Maps. Algoritma untuk menghitung dan menentukan rute yang harus dilalui menggunakan algoritma Dijkstra. Keakuratan hasil hitung dengan menggunakan algoritma Dijkstra mencapai $93 \%$.
\end{abstract}

Kata kunci: Dijkstra, Google Maps API, Android Studio, Graph

\section{PENDAHULUAN}

Pusat perbelanjaan adalah sekelompok usaha ritel dan usaha komersial lainnya yang direncanakan, dikembangkan, dimiliki, dan dikelola sebagai satu properti tunggal [1]. Pusat perbelanjaan dapat ditemui di kota, terutama kota-kota besar seperti di Jakarta. Banyak orang berbondong-bondong datang setiap harinya ke pusat perbelanjaan dari berbagai rentang usia, mulai dari remaja hingga orang dewasa. Sistem belanja online akhir-akhir ini lebih digemari namun tetap saja beberapa orang lainnya lebih memilih untuk berbelanja secara langsung ke pusat perbelanjaan. Alasan-alasan yang mendukungnya seperti dikarenakan berbelanja secara langsung akan lebih mudah mengetahui bagaimana kualitas dan bentuk barang yang akan dibeli secara langsung, selain itu juga belanja 
secara langsung tidak dikenakan biaya pengiriman dan barang yang dibeli dapat didapatkan di hari itu juga [2]. Itulah beberapa alasan mengapa berbelanja secara langsung masih digemari sampai saat ini walaupun tren belanja online sedang ramai-ramainya.

Pusat perbelanjaan pun sekarang ini telah mengalami perubahan fungsi. Dahulu aktivitas di pusat perbelanjaan hanya sebatas berbelanja namun sekarang pusat perbelanjaan sudah difungsikan lebih dari itu. Beberapa orang sekarang ini menggunakan pusat perbelanjaan sebagai tempat untuk menghabiskan waktu, berkumpul bersama, sebagai tempat hiburan, dan mengadakan suatu acara. Orang-orang dari luar daerah akan sulit menemukan pusat perbelanjaan yang ada di Jakarta karena jumlahnya yang sangat banyak. Permasalahan untuk mencari rute inilah yang membuat peneliti membuat sebuah aplikasi yang dapat membantu orang-orang mencari pusat perbelanjaan di Jakarta.

\section{METODOLOGI PENELITIAN}

Metode pengembangan sistem yang penulis gunakan pada penelitian ini yaitu metode Waterfall Model [3]. Metode ini terdiri dari beberapa tahapan yaitu:

1. Tahap requirement, tahap ini akan direncanakan apa saja kebutuhan perangkat yang akan diinginkan oleh pengguna.

2. Tahap design, pada tahap ini direncanakan bagaimana sistem bekerja,

3. Tahap implementation, pada tahap ini penulis akan mulai memangun program yang telah direncanakan atas tahap-tahap berikutnya.

4. Tahap verification, pada tahap ini sistem yang dibuat akan diuji coba dan dicari kesalahannya.

5. Tahap maintenance, pada tahap ini sistem diluncurkan dan dirawat.

\subsection{Dijkstra}

Algoritma Dijkstra adalah sebuah algoritma yang ditemukan oleh Edsger W [4]. Dijkstra yang menggunakan prinsip algoritma rakus (greedy) untuk menentukan rute terpendeknya dalam sebuah graf berarah dengan bobot-bobot sisi yang tidak bernilai negatif, namun hal ini juga berlaku pada graf tak berarah. Prinsip dari greedy pada algoritma Dijkstra menyatakan bahwa pada setiap langkah dipilih sisi yang berbobot minimum dan memasukkannya dalam himpunan solusi. Input algoritma ini adalah sebuah graf $G$ yang berbobot (weighted graph) dan sebuah titik sumber, dengan $\mathrm{V}$ adalah himpunan semua titik (vertex) dan $\mathrm{E}$ himpunan semua sisi dalam graf G. Setiap sisi dari graf ini adalah pasangan titik $(\mathrm{u}, \mathrm{v})$ yang melambangkan hubungan dari titik $\mathrm{u}$ ke titik v. Bobot (weight) dari sebuah sisi dapat dianggap sebagai jarak antara dua titik, yaitu panjang sisi dari dua titik [5]. Proses pencarian pusat perbelanjaan terdekat dijelaskan sebagai berikut.

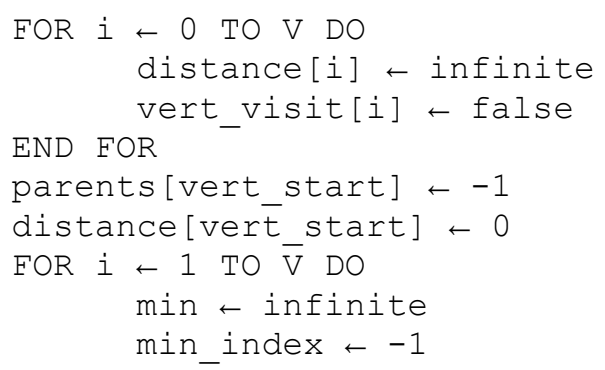




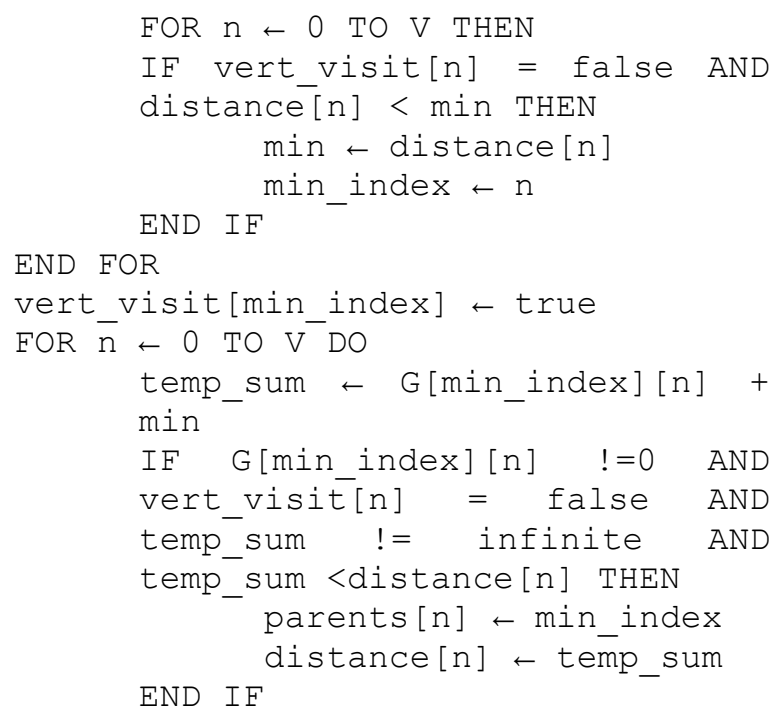

\subsection{Android Studio}

Android Studio merupakan IDE resmi untuk pengembangan aplikasi Android dan bersifat open source atau gratis [6]. Android Studio memiliki fitur editor kode cerdas (Intelligent Code Editor) yang memiliki kemampuan penyelesaian kode, optimalisasi, dan analisis kode yang canggih [7].

\subsection{Google Maps API}

Google Maps adalah layanan aplikasi peta online yang disediakan oleh Google secara gratis. Layanan peta Google Maps secara resmi dapat diakses melalui situs http://maps.google.com. Pada situs tersebut dapat dilihat informasi geografis pada hampir semua permukaan di bumi kecuali daerah kutub utara dan selatan [8].

$$
\text { Google Maps API merupakan }
$$
perkembangan dari google Maps. Dengan menggunakan google Maps API ini, dimungkinkan untuk dapat menggunakan google Maps di dalam website. Meski awalnya hanya JavaScript API, Maps API diperluas untuk menyertakan sebuah API untuk aplikasi Adobe Flash. Keberhasilan google Maps API telah melahirkan sejumlah pesaing antara lain Yahoo! Maps API, Bing Maps Platforn, MapQuest Development Platform dan OpenLayers [9].

\subsection{Unified Modelling Language}

Unified Modelling Language (UML) adalah suatu notasi pendiagraman yang tepat yang mampu mengijinkan suatu desain program untuk direpresentasikan dan didiskusikan [10]. $U M L$ akan digunakan untuk menjelaskan gambaran dari sistem yang dibuat.

\section{HASIL DAN PEMBAHASAN}

Analisis kebutuhan mencakup kebutuhankebutuhan yang harus dapat dilakukan oleh sistem dalam menjawab kebutuhan dari pengguna. Aplikasi yang dirancang harus dapat menerima lokasi yang dimasukkan oleh pengguna. Ketika pengguna telah selesai memasukkan alamat dan mulai menekan tombol cari yang ada di aplikasi sistem harus dapat mencari dan menampilkan hasil yang diinginkan oleh pengguna. Ada juga fitur untuk mencari lokasi pusat perbelanjaan yang terdekat dari posisi pengguna yang diambil dari GPS. Alur kerja aplikasi dijelaskan oleh flowchart seperti pada gambar 1 . 


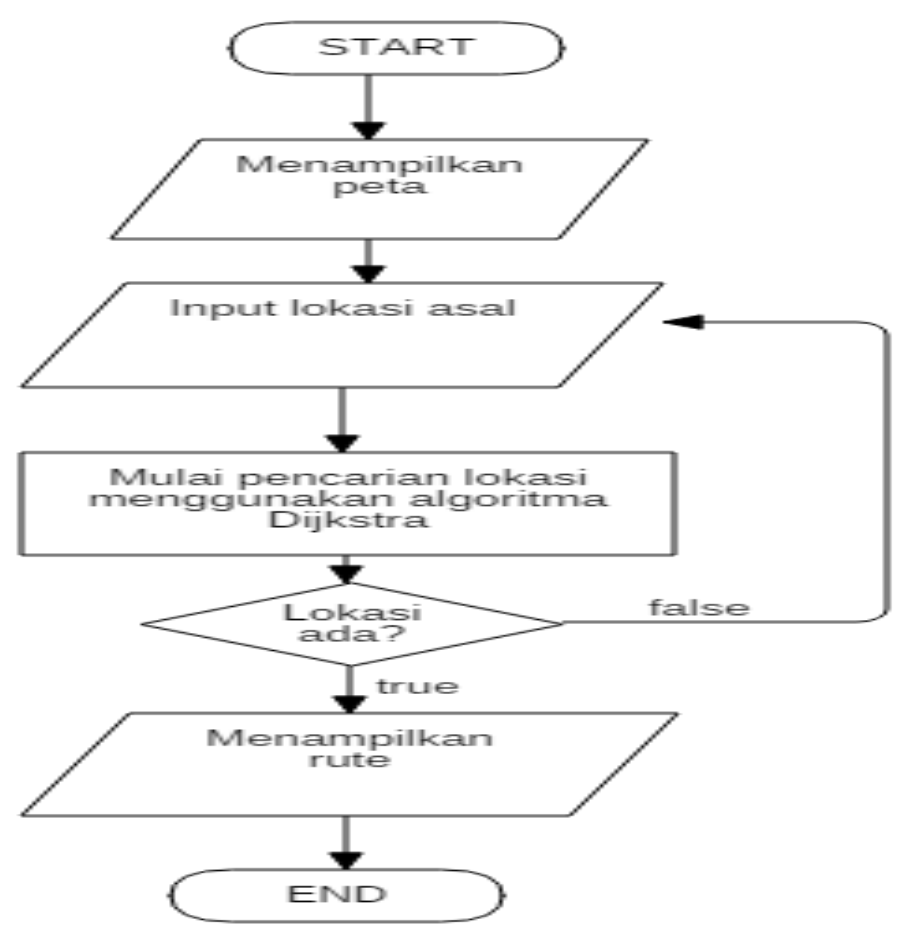

Gambar 1. Flowchart aplikasi

Penggambaran sistem lebih dijelaskan case, yaitu Input location dimana user dapat menggunakan $U M L$ dan terdiri dari empat memasukkan lokasi asal dan memilih lokasi macam diagram. Use case diagram seperti yang tujuan yang disediakan oleh sistem, searching terlihat pada gambar 2 digunakan untuk menggambarkan hubungan antara fungsi yang route to location dimana user dapat tersedia di dalam sistem dan yang dapat mendapatkan informasi menuju pusat digunakan oleh aktor atau user. Pada aplikas perbelanjaan terdekat, dan searching nearest hanya ada satu aktor yaitu user dan tiga buah use location dimana user dapat mendapatkan daftar pusat perbelanjaan terdekat dari posisi sekarang.

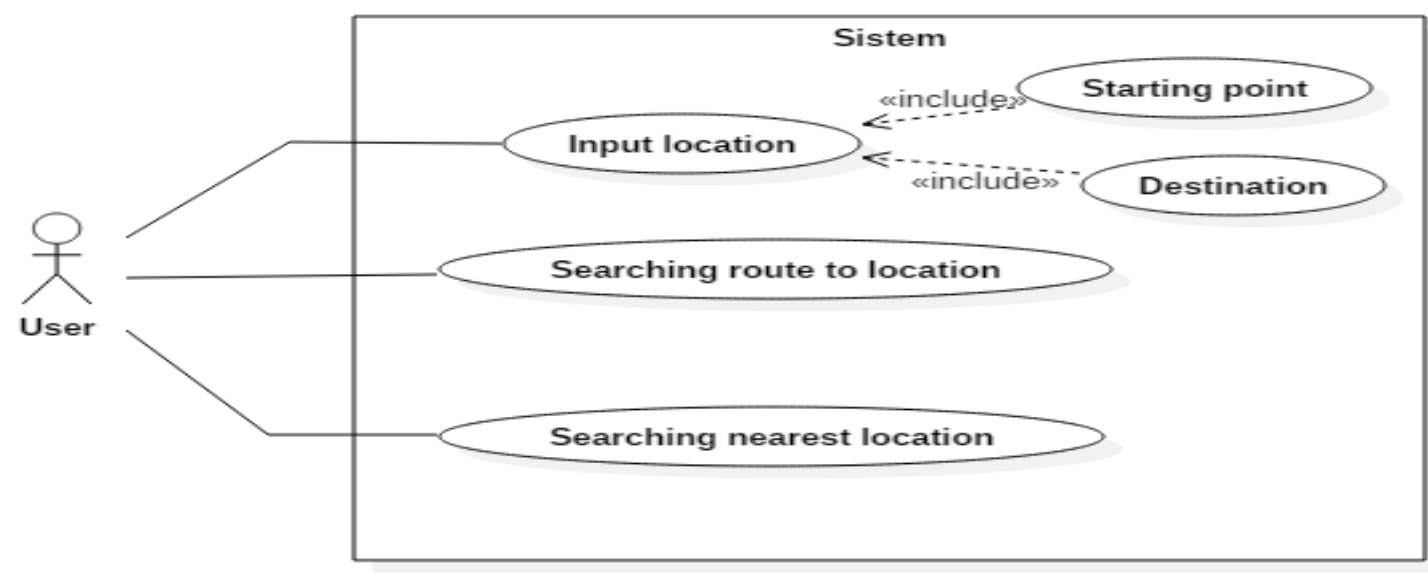

Gambar 2. Use Case Diagram 


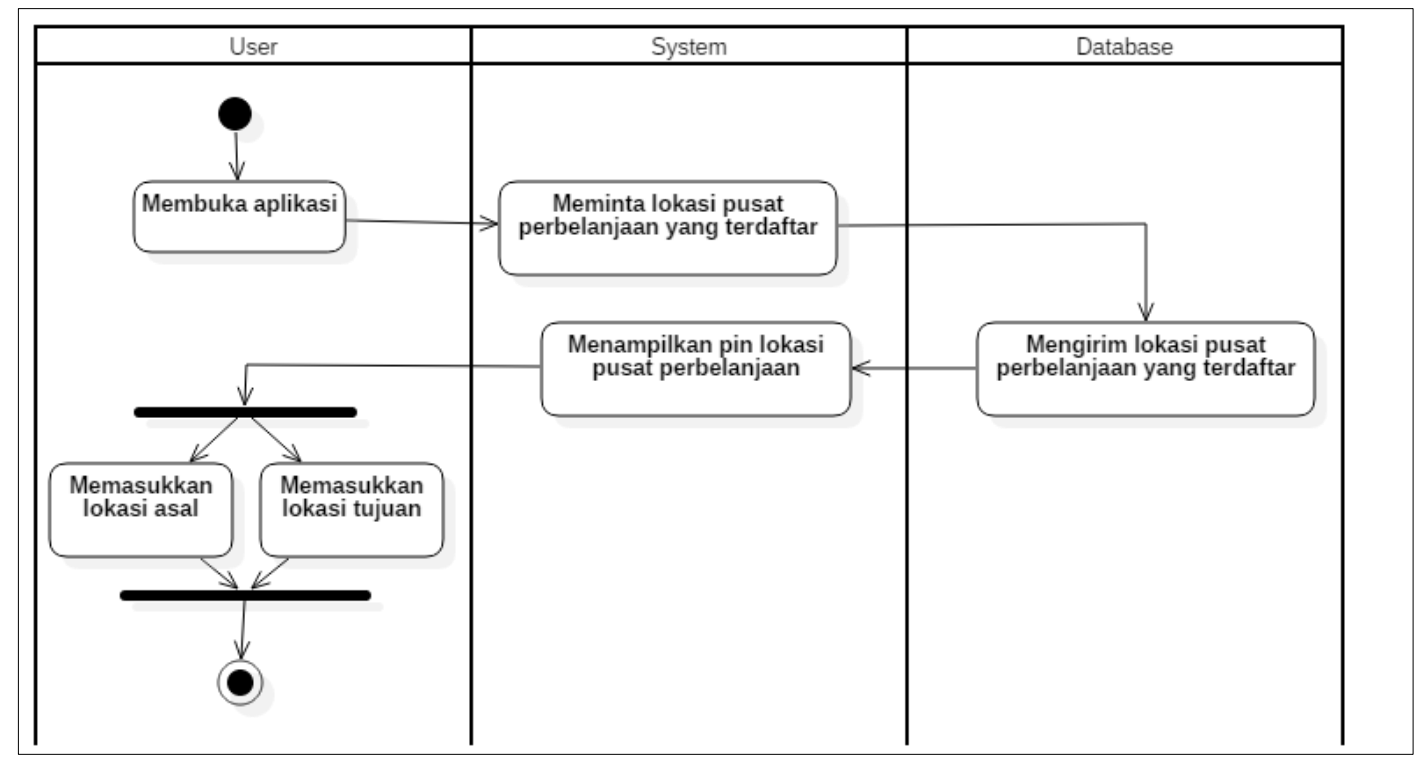

Gambar 3. Activity input location

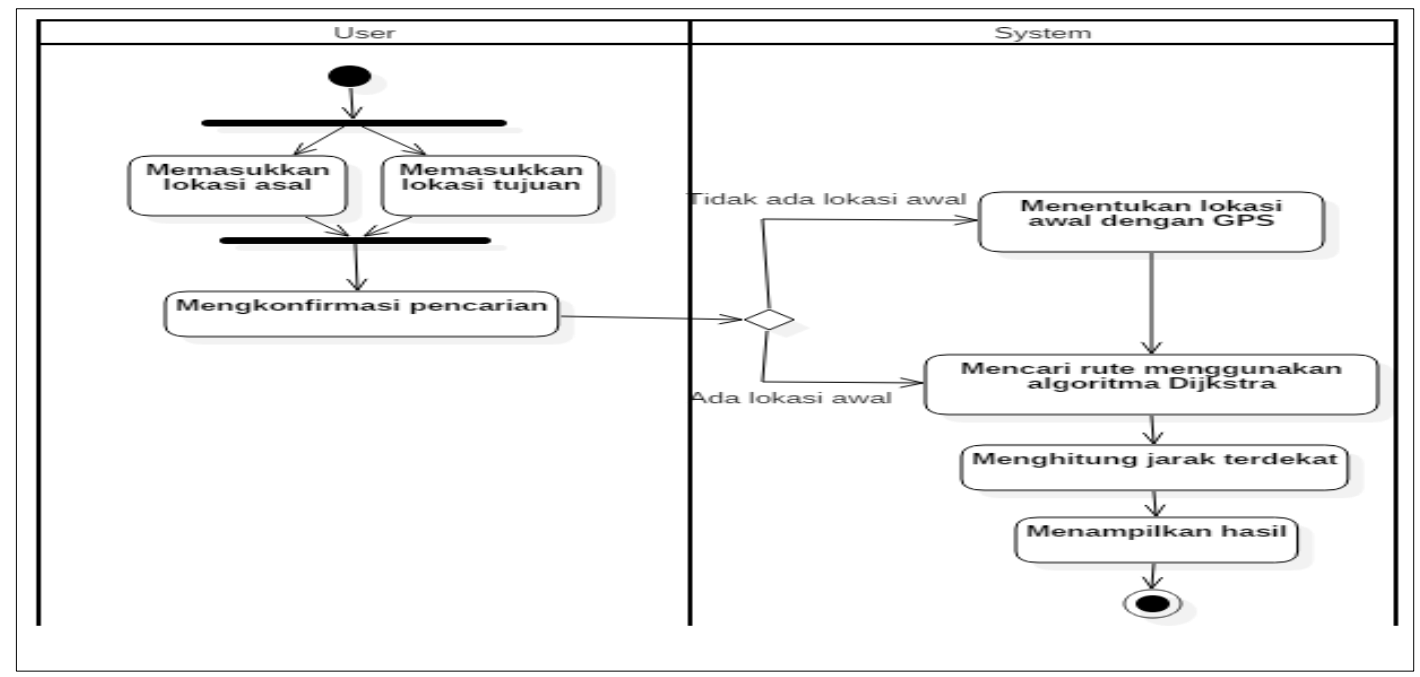

Gambar 4. Activity searching route to location

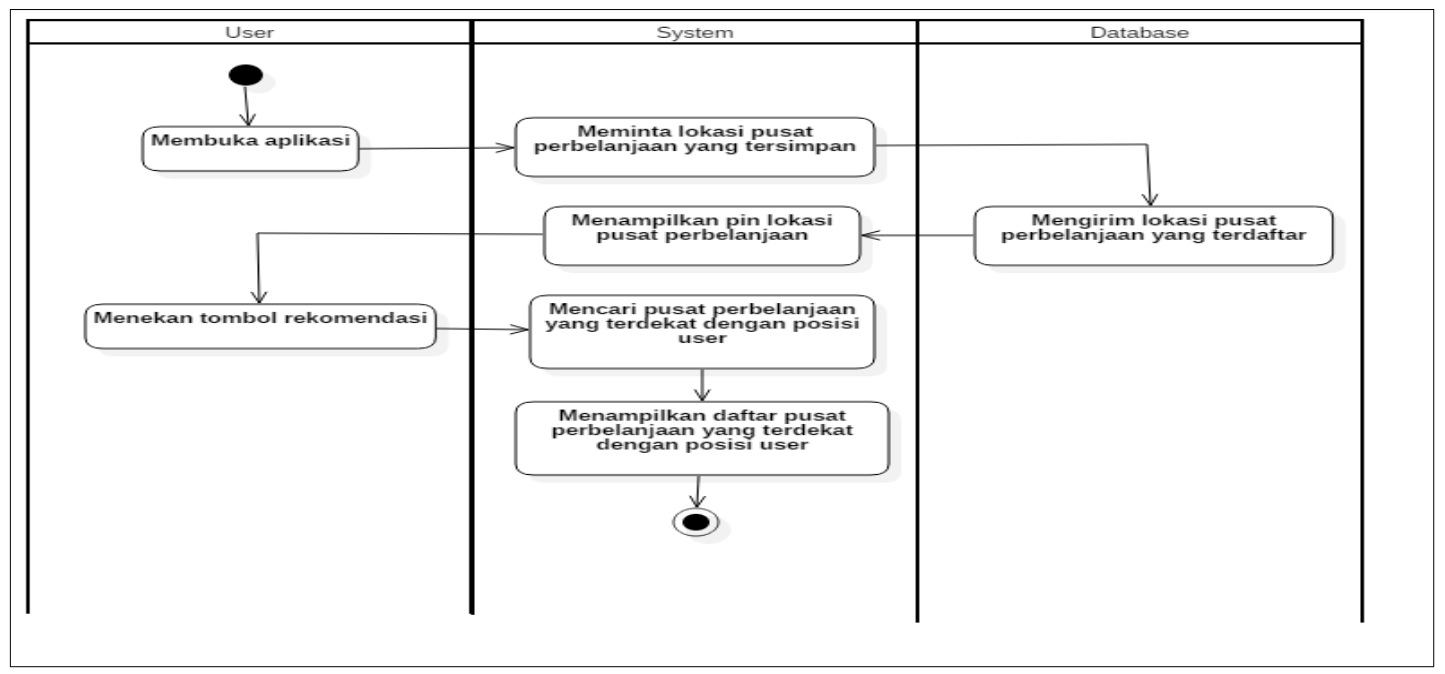

Gambar 5. Activity searching nearest location 
Activity diagram digambarkan seperti pada gambar 3, 4, dan 5. Activity input location pada gambar 3 menjelaskan setiap proses aktivitas yang perlu dieksekusi untuk menjalankan proses memasukkan lokasi yang dilakukan oleh user kepada sistem. Activity searching route to location pada gambar 4 menjelaskan alur proses aktivitas untuk mengeksekusi pencarian menemukan rute ke lokasi yang diinginkan oleh user. Activity searching nearest location pada gambar 5 adalah fitur tambahan yang disediakan di dalam aplikasi.

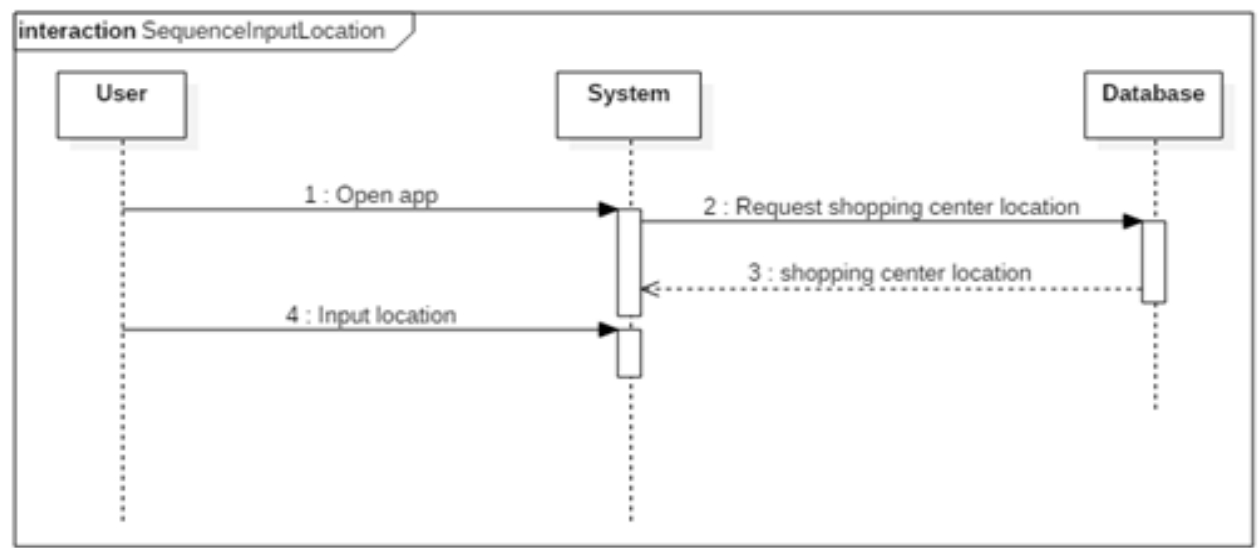

Gambar 6. Sequence input location

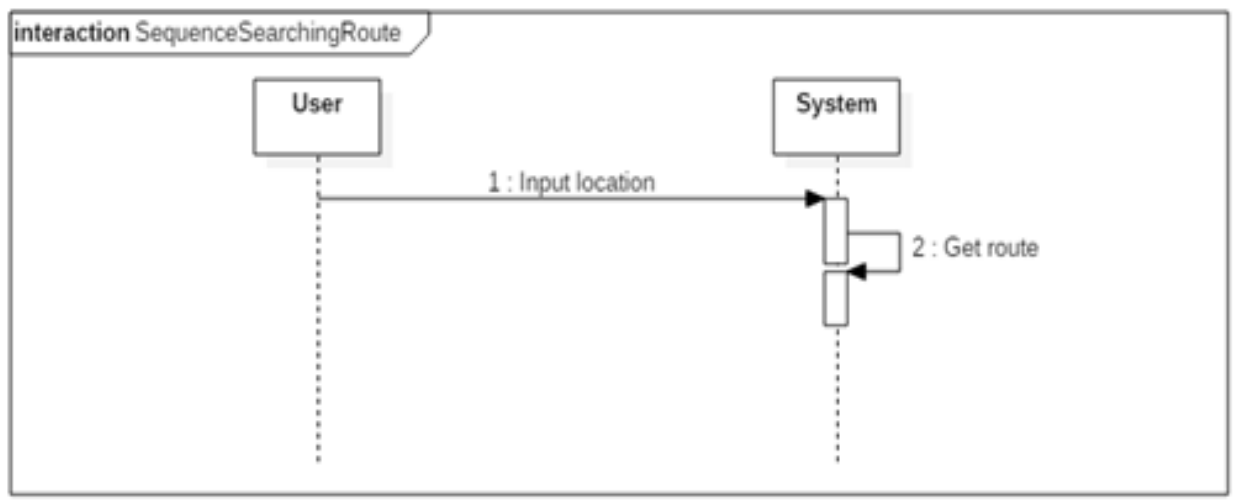

Gambar 7. Sequence searching route to location

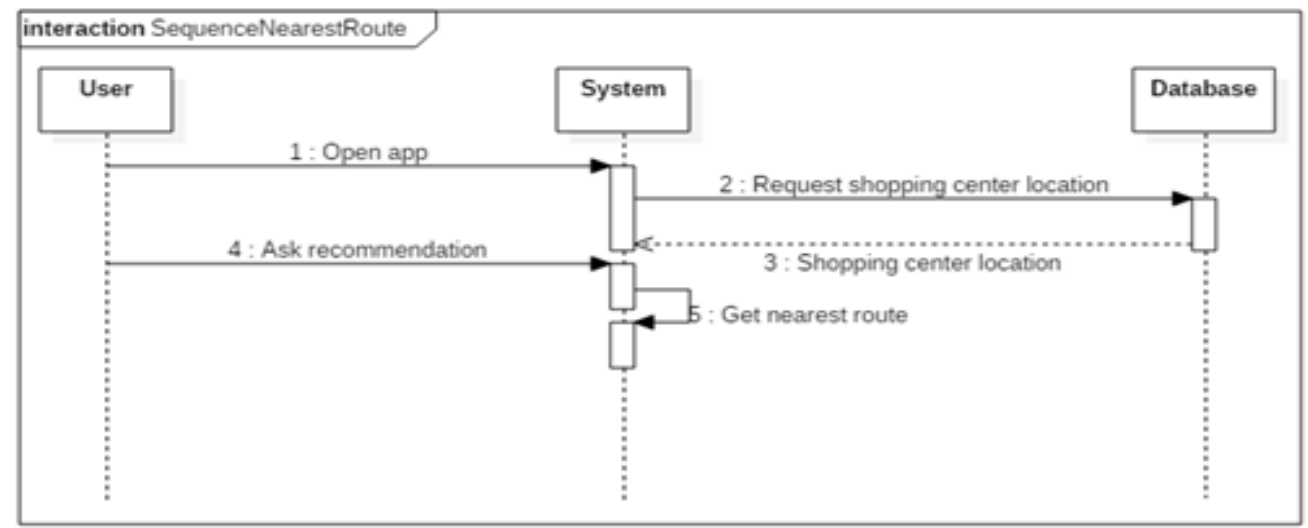

Gambar 8. Sequence searching nearest location 
Sequence diagram digambarkan seperti pada gambar 6, 7, dan 8. Sequence input location pada gambar 6 menjelaskan tentang urutan pengiriman pesan yang terjadi saat user membuka dan memasukkan lokasi. Sequence searching route to location pada gambar 7 menjelaskan tentang pengiriman pesan di dalam sistem saat user meminta sistem untuk menampilkan rute menuju lokasi pusat perbelanjaan yang diinginkan oleh user. Sequence searching to nearest location pada gambar 8 menjelaskan alur pengiriman pesan di saat user meminta sistem untuk memberikan lokasi pusat perbelanjaan yang ada di sekitarnya.

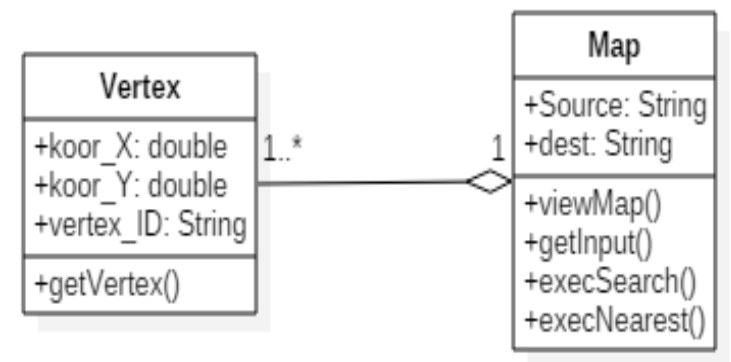

Gambar 9. Class diagram

Class diagram seperti pada gambar 9 memiliki dua objek, yaitu objek Vertex dan Maps. Objek Vertex digunakan untuk menyimpan informasi tentang vertex atau titik yang nantinya akan ditampilkan pada peta. Objek Map adalah pusat dari operasi yang dikerjakan oleh sistem, mulai dari menampilkan peta, menerima input, sampai menghitung dan mencari rute terdekat dari user.

Perancangan database yang digunakan di dalam aplikasi yang dalam penelitian ini dirancang dengan menggunakan model Entity Relationship Diagram (ERD) dengan notasi crowsfoot, dimana ERD yang akan digunakan terlihat seperti pada gambar 10 .

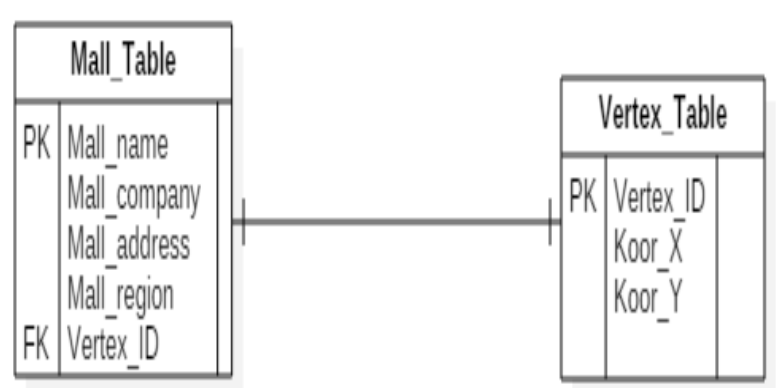

Gambar 10. Entity relationship diagram

Database terdiri dari dua tabel, yaitu tabel untuk vertex atau titik yang diberi nama Vertex_Table dan tabel untuk menyimpan informasi lokasi pusat perbelanjaan yang diberi nama Mall_Table. Tabel Mall_Table memiliki relasi satu ke satu (one-to-one relationship) dengan tabel Vertex_Table karena sebuah pusat perbelanjaan hanya bisa menempati satu tempat atau vertex, begitu juga sebaliknya diaman satu tempat atau vertex hanya bisa ditempati oleh satu pusat perbelanjaan.

Tampilan aplikasi terlihat seperti pada gambar 11. Terdapat peta yang mendominasi sebagian layar lebih. Dua buah label untuk menunjukkan lokasi tujuan user dan untuk menunjukkan jarak. Sebuah edit box dimana user dapat memasukkan lokasi asal ataupun tidak (jika ingin menjadikan lokasi sekarang user sebagai lokasi asal). Sebuah button untuk memulai pencarian pusat perbelanjaan terdekat. Tiga buah button untuk menampilkan rekomendasi pusat perbelanjaan yang terdekat yang diatur tidak terlihat sampai button dengan caption 'telusuri' ditekan oleh user. Keluaran yang ditampilkan oleh aplikasi terlihat seperti pada gambar 12 . 


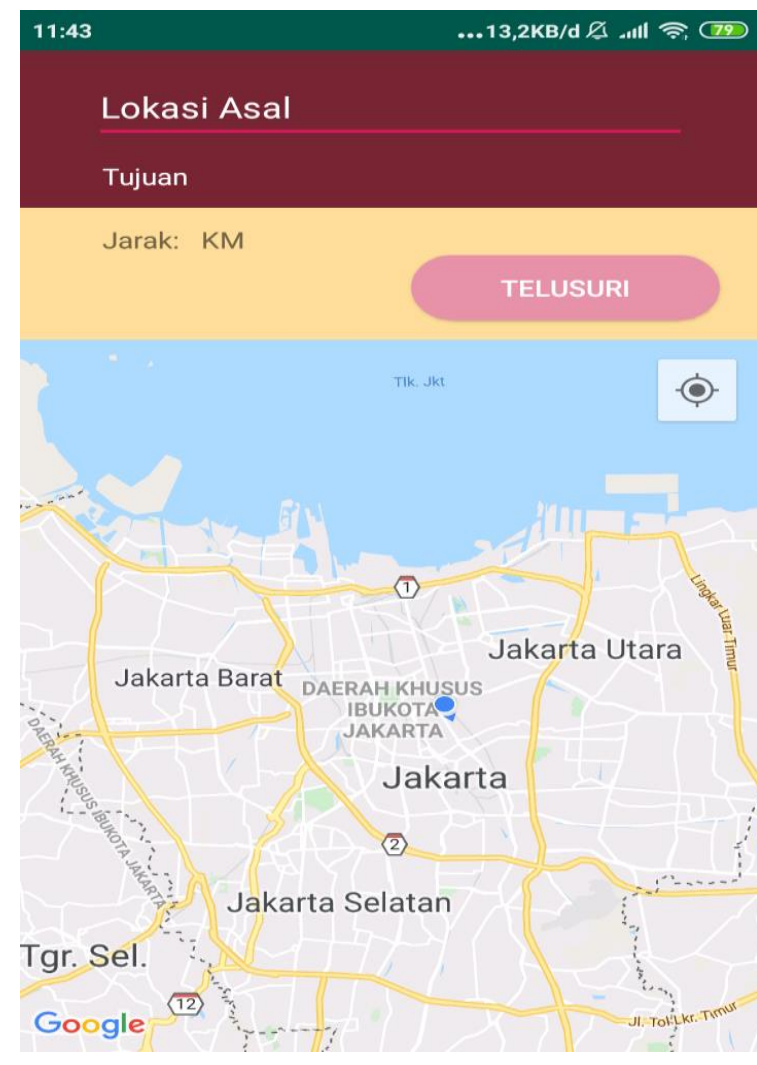

Gambar 11. Tampilan awal aplikasi
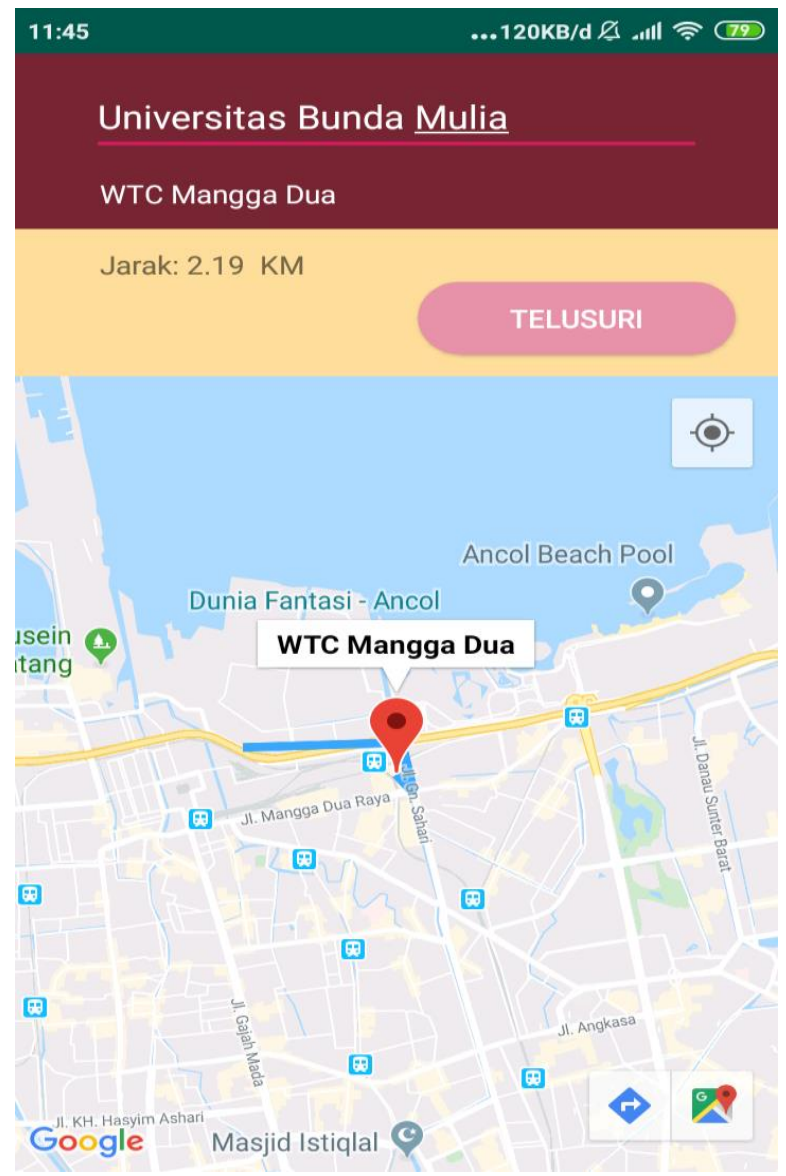

Gambar 12. Tampilan akhir aplikasi
Pengujian dilakukan dengan menggunakan sepuluh lokasi asal dan ketiga lokasi yang direkomendasikannya, menghasilkan total tiga puluh pengujian Hasil dari pengujian algoritma akan terlihat seperti pada tabel 1. Jarak yang didapatkan dari menghitung jarak terdekat antara kedua vertex yang saling bertetanggaan. Jarak tersebut diakumulasikan dari lokasi asal menuju lokasi tujuan baru dikatakan sebagai jarak dari titik asal menuju titik tujuan.

Pengujian yang dilakukan dalam tiga puluh percobaan menunjukkan terdapat 28 perhitungan dengan hasil yang valid dan dua perhitungan dengan hasil yang tidak valid. Salah satu hasil yang tidak valid terdapat saat dilakukan pengujian dari La Piazza menuju Mal Kelapa Gading dimana sistem menghitung jaraknya 0.9 KM sementara peneliti menghitungnya $0.91 \mathrm{KM}$. Hitungan tidak valid kedua ditemukan pada saat melakukan pengujian dari Mall of Indonesia menuju La Piazza dimana hasil dari sistem menunjukkan jarak sebesar 2.62 KM sementara dari hitungan peneliti adalah 2.67 KM. Persentase keberhasilan dilakukan dengan menggunakan rumus pada persamaan (1) dan menunjukkan tingkat keberhasilan sebesar 93\%.

Tkt Keberhasilan $=\frac{\text { Pengujian yang Valid }}{\text { Totla Pengujian }}$ 
Tabel 1. Hasil Pengujian

\begin{tabular}{|c|c|c|c|c|c|}
\hline NO & Lokasi Asal & Lokasi Tujuan & Jarak (KM) & Hitungan & Validasi \\
\hline \multirow[t]{3}{*}{1} & Universitas & WTC Mangga Dua & 2.19 & 2.19 & Valid \\
\hline & Bunda Mulia & ITC Mangga Dua & 2.54 & 2.54 & Valid \\
\hline & & Mangga Dua Mal & 2.8 & 2.8 & Valid \\
\hline \multirow[t]{3}{*}{2} & Golden Truly & Haroo Pasar Baru & 0.88 & 0.88 & Valid \\
\hline & & Istana Pasar Baru & 0.99 & 0.99 & Valid \\
\hline & & Pusat Perbelanjaan MC & 1.66 & 1.66 & Valid \\
\hline \multirow[t]{3}{*}{3} & ITC Roxy Mas & Mal Ciputra & 1.82 & 1.82 & Valid \\
\hline & & Plaza Gajah Mada & 2.46 & 2.46 & Valid \\
\hline & & Central Park & 2.82 & 2.82 & Valid \\
\hline \multirow[t]{3}{*}{4} & Mal Cilandak & Cilandak Town Square & 2.88 & 2.88 & Valid \\
\hline & & Mall Pejaten Village & 3.43 & 3.43 & Valid \\
\hline & & Poins Square & 5.88 & 5.88 & Valid \\
\hline \multirow[t]{3}{*}{5} & La Piazza & Mal Kelapa Gading & 0.9 & 0.91 & Tidak Valid \\
\hline & & Mal of Indonesia & 2.67 & 2.67 & Valid \\
\hline & & Mal artha Gading & 3.48 & 3.48 & Valid \\
\hline \multirow[t]{3}{*}{6} & Mall Of & Mall Artha Gading & 1.71 & 1.71 & Valid \\
\hline & Indonesia & ITC Cempaka Mas Mega & 2.62 & 2.62 & Valid \\
\hline & & La Piazza & 2.62 & 2.67 & Tidak Valid \\
\hline \multirow[t]{3}{*}{7} & Plaza Atrium & Plaza Kenari Mas & 1.89 & 1.89 & Valid \\
\hline & & Menteng Huis & 2.01 & 2.01 & Valid \\
\hline & & Golden Truly & 2.76 & 2.76 & Valid \\
\hline \multirow[t]{3}{*}{8} & Grand Cakung & Pulo Gading Trade Centre & 4.85 & 4.85 & Valid \\
\hline & & Plaza Buaran & 6.57 & 6.57 & Valid \\
\hline & & Pokets & 7.85 & 7.85 & Valid \\
\hline \multirow[t]{3}{*}{9} & Grand Paragon & Plaza Gajah Mada & 1.05 & 1.05 & Valid \\
\hline & & Lindeteves trade Center & 2.46 & 2.46 & Valid \\
\hline & & Istana Pasar Baru & 2.49 & 2.49 & Valid \\
\hline \multirow[t]{3}{*}{10} & Mal Ciputra & Central Park & 1.48 & 1.48 & Valid \\
\hline & & Mal Taman Anggrek & 1.59 & 1.59 & Valid \\
\hline & & ITC Roxy Mas & 1.82 & 1.82 & Valid \\
\hline
\end{tabular}

\section{KESIMPULAN}

Kesimpulan dari penelitian yang dilakukan adalah algoritma Dijkstra dapat diimplementasikan untuk mencari jarak terpendek menuju pusat perbelanjaan terdekat dengan keakuratan $93 \%$ dengan perbandingan yang dilakukan antara hasil perhitungan yang dilakukan oleh sistem dan hasil perhitungan yang dilakukan oleh peneliti. Implementasi algoritma Dijkstra ke dalam Google Maps API juga dapat dilakukan jika menggunakan database vertex yang didata sendiri karena untuk implementasi menggunakan vertex dari Google Maps, dibutuhkan key yang harus diperoleh dengan membelinya.

\section{DAFTAR PUSTAKA}

[1] G. T. Sari, "Pusat perbelanjaan mall di kabupaten kubu raya," Jurnal online mahasiswa Arsitektur Universitas Tanjungpura, Vol. 5, no. 2 September 2017, pp. 1-12, 2017.

[2] U. Widowati, "10 Alasan Belanja Langsung Lebih Asyik dari Belanja Online," CNN Indonesia, 2015. [Online]. Available: https://www.cnnindonesia.com/gayahidup/20150729080646-277-68749/10alasan-belanja-langsung-lebih-asyik-daribelanja-online. [Accessed: 13-Sep-2019]. 
[3] M. Tabrani and P. Eni, "Penerapan Metode Waterfall Pada Sistem Informasi Inventori Pt. Pangan Sehat Sejahtera," J. Inkofar, vol. 1, no. 2, pp. 30-40, 2017.

[4] A. Zaki, "Algoritma Dijkstra: Teori Dan Aplikasinya," J. Mat. UNAND, vol. 6, no. 4, pp. 1-8, 2018.

[5] K. S. Zalukhu, "Implementasi Algoritma Dijkstra dalam Pencarian Rute Efektif Menghindari Kemacetan saat Jam Sibuk (Studi Kasus : Pasar Nou Kota Gunungsitoli dan Sekitarnya)," 2018.

[6] Andi Juansyah, "Pembangunan Aplikasi Child Tracker Berbasis Assisted - Global Positioning System ( A-GPS ) Dengan Platform Android," J. Ilm. Komput. dan Inform., vol. 1, no. 1, pp. 1-8, 2015.

[7] D. E. Palupi, M. A. Akbar, and A. H. Brata, "Pengembangan Aplikasi Traffic Light ETilang Menggunakan Google Geofencing API Berbasis Android," J. Pengemb. Teknol. Inf. dan Ilmu Komput. Univ. Brawijaya, vol. 2, no. 2, pp. 6982-6988, 2018.

[8] M. S. Amri, "Membangun Sistem Navigasi Di Surabaya Menggunakan Google Maps Api," Pens Its, vol. 1, no. Proposal 2013, pp. 1-5, 2010.

[9] F. Masykur, "Implementasi Sistem Informasi Geografis Menggunakan Google Maps Api Dalam Pemetaan Asal Mahasiswa," J. SIMETRIS, vol. 5, no. 2, pp. 181-186, 2014.

[10] J. O. Agung, T. Efendi, and H. Agung, "Analisis Perbandingan Algoritma FloydWarshall Dengan Algoritma Bellman-Ford Dalam Pencarian Rute Terpendek Menuju Museum di Jakarta," J. Sains dan Teknol., vol. 5, no. 1, pp. 1-7, 2018. 